\title{
OPPORTUNITIES FOR USING RENEWABLE ENERGY SOURCES IN BULGARIA
}

\author{
D. Markova*, S. Platikanov, M. Konstantinoff, P. Tsankov \\ Technical University of Gabrovo, Faculty of Electrical Engineering and \\ Electronics, 4 Hadji Dimitar Str., 5300 Gabrovo, Bulgaria
}

\begin{abstract}
Summary: Bulgaria has one of Europe's richest renewable energy resource bases. This paper presents an assessment of Bulgarian renewable sources of energy as a stage for increasing the share of these resources in the country's total energy balance, to the end of the improvement of the environment, stimulation of industrial development and creation of new jobs. It considers the theoretical (total) resource potential for solar, wind, both large and small hydro, geothermal, and biomass and waste sources. The paper presents the present status of renewable energy technologies and their installed capacities. The opportunities and constraints for development and use of renewable energy are considered.
\end{abstract}

Keywords: theoretical resource potential, solar, wind, hydro, geothermal, biomass.

\section{INTRODUCTION}

In the last decade there has been a growing interest in renewable energy sources applications. Alternative energy sources like solar, wind, hydro, geothermal and biomass have several advantages over non-renewable ones. They are non-polluting, modular and free.

The Bulgarian renewable energy resource base is one of the richest in Europe. The country has very well developed agricultural bases and extensive forests. Geothermal resources are plentiful and have been used for thousands of years both as a source of energy and for health reasons. Bulgaria has an important small hydro resource base which has been successfully exploited to generate electricity for nearly one hundred years. Rich solar resources have been used for thousands of years for crop drying. Traditional Bulgarian architecture has incorporated passive solar designs for hundreds of years. The country has a relatively good wind resource base. Other renewable resources, including municipal and industrial wastes offer good opportunities for energy utilisation.

This paper presents an assessment of Bulgarian renewable sources of energy as a stage in increasing the contribution of these resources in the country's total energy balance, aiming at the improvement of the environment, the stimulation of industrial development and creation of new jobs.

\section{THEORETICAL RENEWABLE ENERGY POTENTIAL}

Total or theoretical resource potential is defined as the total amount of the energy source from which energy can be generated.

Solar resource theoretical potential is the solar energy on the earth surface that is expressed as the average kilowatt-hours ( $\mathrm{kWh}$ ) of thermal energy incident on a square metre of horizontal area. This is given in daily, monthly or annual averages to obtain the theoretical or total energy available. The Institute of Hydrology and Meteorology (IHM) of the Bulgarian Academy of Sciences (BAS) has sunshine hour data from 45 sites covering 30 years and actual solar radiation (SR) measurements from 5-6 stations $[1,2,3]$. The results from the analysis of this data using a correlation relating solar irradiation to sunshine hours are shown in Fig. 1. The country is divided into three solar regions: area)

$$
\text { I - SR }<1450 \mathrm{kWh} / \mathrm{m}^{2} / \text { year }(41 \% \text { of land }
$$
land area)

$$
\text { II - SR: } 1450-1500 \mathrm{kWh} / \mathrm{m}^{2} / \text { year }(52 \% \text { of }
$$
area)

$$
\text { III - SR }>1500 \mathrm{kWh} / \mathrm{m}^{2} / \text { year }(7 \% \text { of land }
$$

This gives a figure for the energy falling on Bulgarian soil over one year of approximately 12 995 million tonnes of oil equivalent (Mtoe). 
The theoretical potential for wind is the energy contained in the wind at a certain height above the ground level. This potential is commonly expressed as the average annual wind speed for a location of 10 metres above the ground level. Data of the wind speed and the wind direction has been obtained by the IHM from 419 meteorological stations over 30 years [1-3]. Figure 2 shows a wind resource map. The country is split into four wind zones. The only two zones of interest for wind electricity generation are zones with $5-7 \mathrm{~m} / \mathrm{s}$ and more than $7 \mathrm{~m} / \mathrm{s}$. An estimate of the land area in these zones is $1430 \mathrm{~km}^{2}$.
Total potential for small hydro-electric power is commonly expressed in terms of Gigawatthours (GWh) of electrical energy which could be generated from this source per annum, and estimated from river flow rates and the change in height of the rivers over sections of their length. The resource assessment has been based on existing data (over many years). Based on the analysis of hydro resources they have been divided into categories: large hydro of above $2 \mathrm{MW}$ and small hydro of below $2 \mathrm{MW}$ installed capacity. Table 1 shows the theoretical hydro potential in $\mathrm{GWh} /$ year and ktoe.

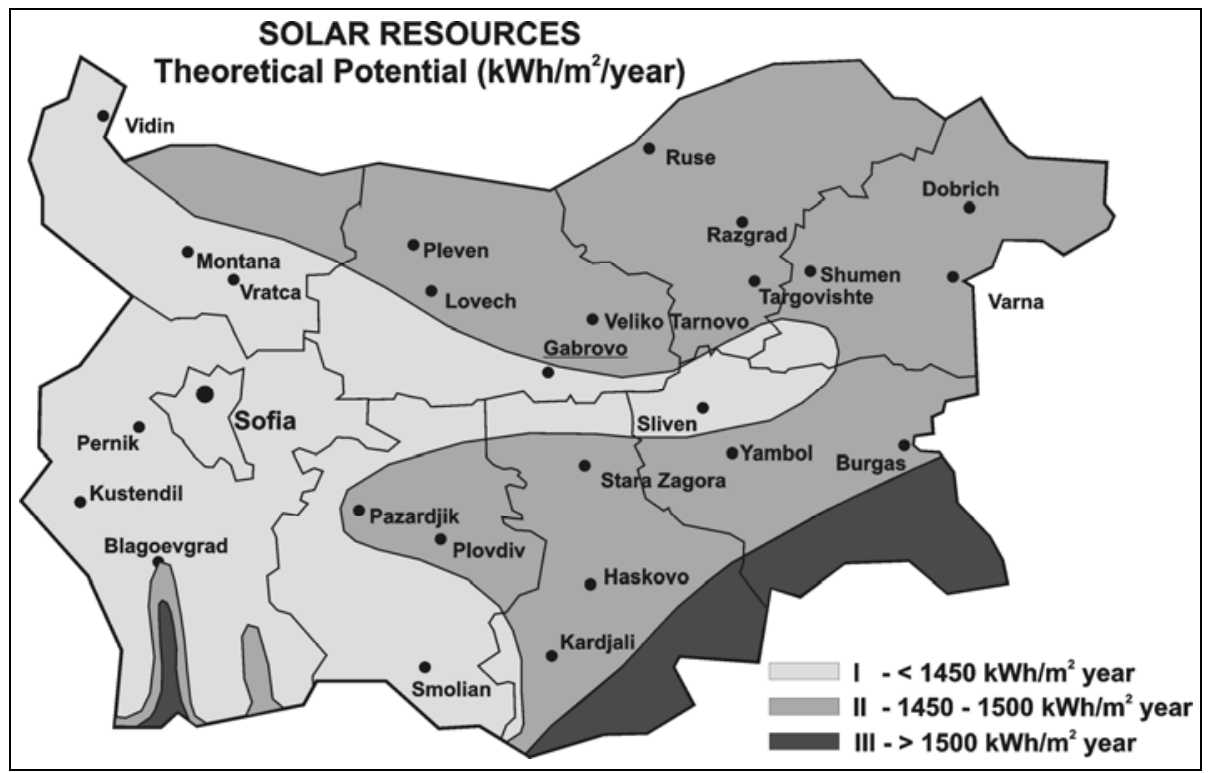

Figure 1. Solar Resources in Bulgaria

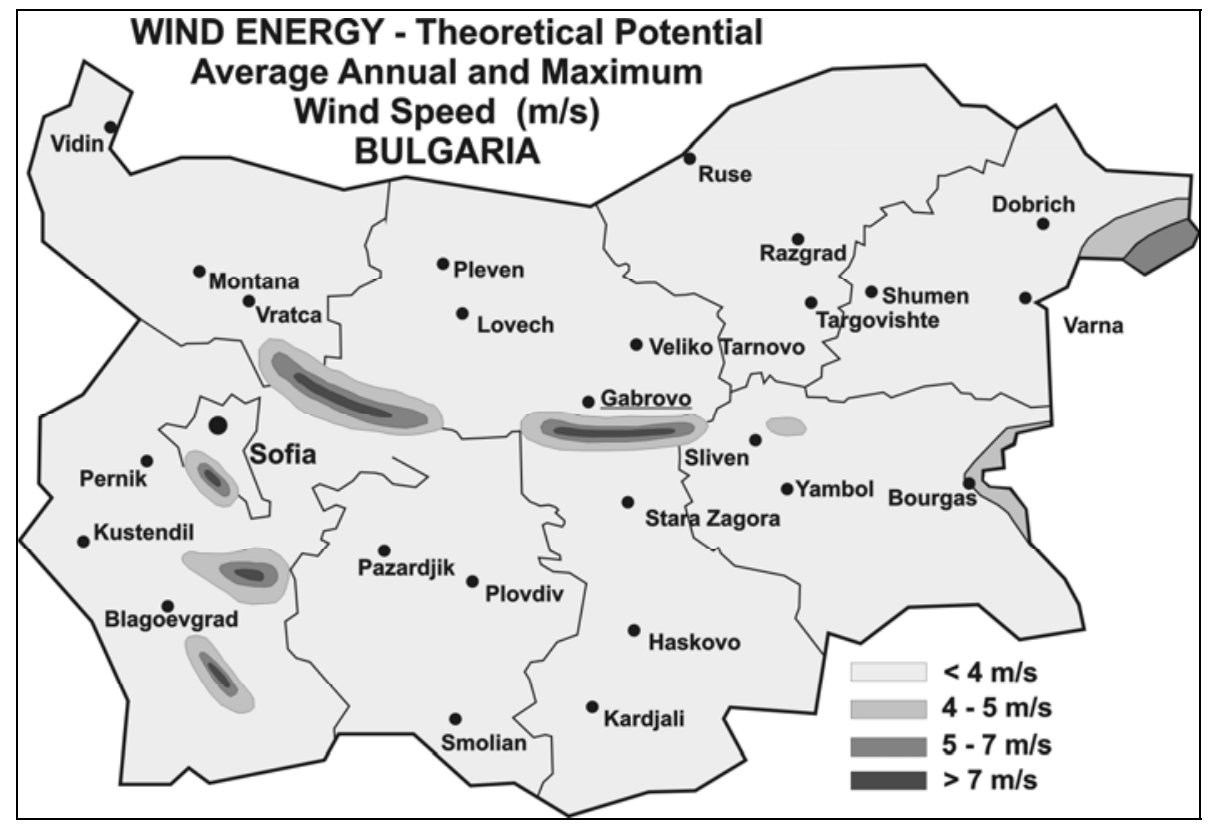

Figure 2. Areas of High Wind Speed in Bulgaria 
Total potential for small hydro-electric power is commonly expressed in terms of Gigawatthours (GWh) of electrical energy which could be generated from this source per annum, and estimated from river flow rates and the change in

Theoretical potential for geothermal, where Bulgarian sources are primarily for thermal use, is thermal energy contained in thermal waters. Energy is expressed in Terajoules per annum $(\mathrm{TJ} / \mathrm{yr})$ for comparison purposes with energy balance data and it is calculated from the flow rate and the temperature of thermal waters. Theoretical potential is taken only from known resources. The total geothermal potential has been assessed on the basis of data from more than 120 different sites around the country. It is shown in Table 2.

Theoretical potential for biomass and waste is first expressed in available tonnes of resource per annum. The theoretical potential depends on the calorific value of each waste or biomass resource.
Tonnes of biomass are defined by either the amount of waste produced (for industrial, animal and municipal wastes) or by the land area which is under crops (for agricultural wastes and for energy crops) and produces a certain yield on the annual basis.

The number of biomass sources is large. The main categories are: forestry residues; energy crops wood; energy crops - liquid biofuels; agricultural solid waste; agricultural liquid waste; industrial solid waste; industrial liquid waste; municipal solid waste; municipal liquid waste. Table 3 shows biomass resources by resource type. The relative proportions of biomass categories are shown in Figure 3.

All theoretical potential can be expressed in common terms: tonnes of oil equivalent (toe) or Terajoules (TJ), in order to allow comparison. The profile of Bulgarian theoretical potential for renewable energy resources is summarised in Table 4 and is shown in Figure 4.

Table 1. Hydro Resources - Theoretical Potential and Installed Capacity

\begin{tabular}{|c|c|c|c|c|c|}
\hline \multirow[t]{2}{*}{ Region } & \multicolumn{2}{|c|}{ Theoretical Potential, GWh/yr } & \multicolumn{2}{|c|}{$\begin{array}{c}\text { Theoretical Potential, } \\
\text { ktoe/yr }\end{array}$} & $\begin{array}{c}\text { Installed } \\
\text { Capacity, kW }\end{array}$ \\
\hline & Large Hydro & Small Hydro & Large Hydro & Small Hydro & Small Hydro \\
\hline Bourgas & 700 & 139 & 60 & 11.914 & - \\
\hline Haskovo & 3730 & 92 & 319.714 & 7.885 & 1025 \\
\hline Lovech & 2975 & 216 & 255 & 18.514 & 8824 \\
\hline Montana & 2485 & 356 & 213 & 30.514 & 5127 \\
\hline Plovdiv & 8160 & 181 & 699.429 & 15.514 & 2825 \\
\hline Rousse & 875 & 58 & 75 & 4.971 & - \\
\hline Sofia City & 875 & 34 & 75 & 2.914 & 1380 \\
\hline Sofia Region & 5050 & 426 & 432.857 & 36.514 & 5653 \\
\hline Varna & 175 & 25 & 15 & 2.143 & 400 \\
\hline Total & 25025 & 1527 & 2145 & 130.866 & 25234 \\
\hline
\end{tabular}

Table 2. Geothermal Resources - Theoretical Potential and Installed Capacity

\begin{tabular}{|l|r|r|r|r|}
\hline \multirow{2}{*}{\multicolumn{1}{c|}{ Region }} & \multicolumn{2}{c|}{ Theoretical Potential } & \multicolumn{2}{c|}{ Installed Capacity } \\
\cline { 2 - 5 } & TJ/year & toe/year & TJ/year & toe/year \\
\hline Bourgas & 453 & 10786 & 43.5 & 1036 \\
\hline Haskovo & 711 & 16928 & 72.5 & 1726 \\
\hline Lovech & 2213 & 52690 & 174.0 & 4143 \\
\hline Montana & 260 & 6190 & 7.3 & 174 \\
\hline Plovdiv & 2566 & 61095 & 261.1 & 6217 \\
\hline Sofia City & 674 & 16048 & 58.0 & 1381 \\
\hline Sofia Region & 2983 & 71024 & 247.0 & 5881 \\
\hline Varna & 3996 & 91142 & 507.6 & 12086 \\
\hline Total & 13856 & 325903 & 1371 & 32644 \\
\hline
\end{tabular}


Table 3. Bulgarian Biomass Theoretical Potential

\begin{tabular}{|c|c|c|c|c|c|}
\hline $\begin{array}{c}\text { Agric. Solid } \\
\text { Waste, toe }\end{array}$ & $\begin{array}{c}\text { Energy Crops, } \\
\text { toe }\end{array}$ & $\begin{array}{c}\text { Firewood, } \\
\text { toe }\end{array}$ & $\begin{array}{c}\text { Munic. Solid } \\
\text { Waste, toe }\end{array}$ & $\begin{array}{c}\text { Others, } \\
\text { toe }\end{array}$ & $\begin{array}{c}\text { Total, } \\
\text { toe }\end{array}$ \\
\hline 1877941 & 842830 & 547162 & 306802 & 33225 & 3607962 \\
\hline
\end{tabular}

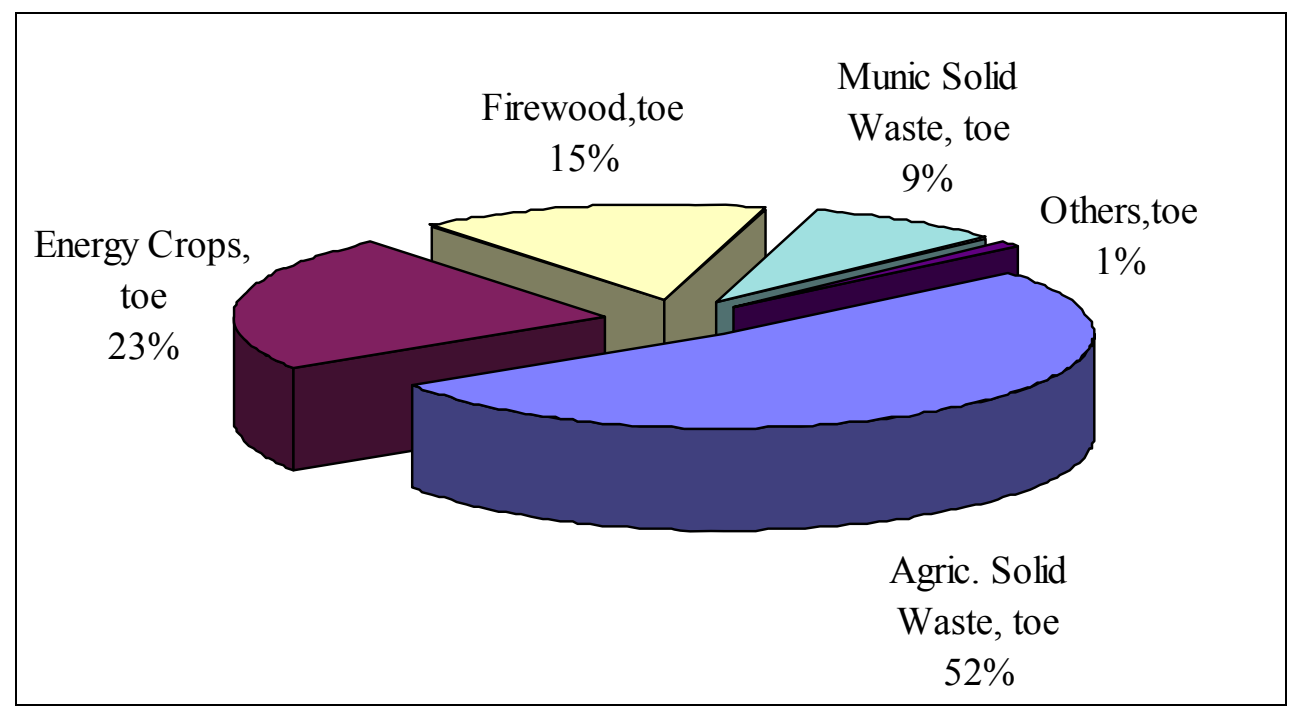

Figure 3. Biomass Theoretical Potential

Table 4. Bulgarian Renewable Energy Resource

\begin{tabular}{|c|c|c|c|c|c|c|}
\hline \multicolumn{2}{|c|}{ Resource } & Solar & Wind & $\begin{array}{c}\text { Hydro } \\
\text { (Large }+ \\
\text { Small) }\end{array}$ & Geothermal & $\begin{array}{c}\text { Biomass } \\
\text { and } \\
\text { Waste }\end{array}$ \\
\hline $\begin{array}{c}\text { Total } \\
\text { Resource Avai- } \\
\text { lable }\end{array}$ & ktoe & 12955000 & 75000 & 2276 & 326 & 3608 \\
\cline { 2 - 7 } & TJ & 544110000 & 3150000 & 95587 & 13856 & 151534 \\
\hline
\end{tabular}

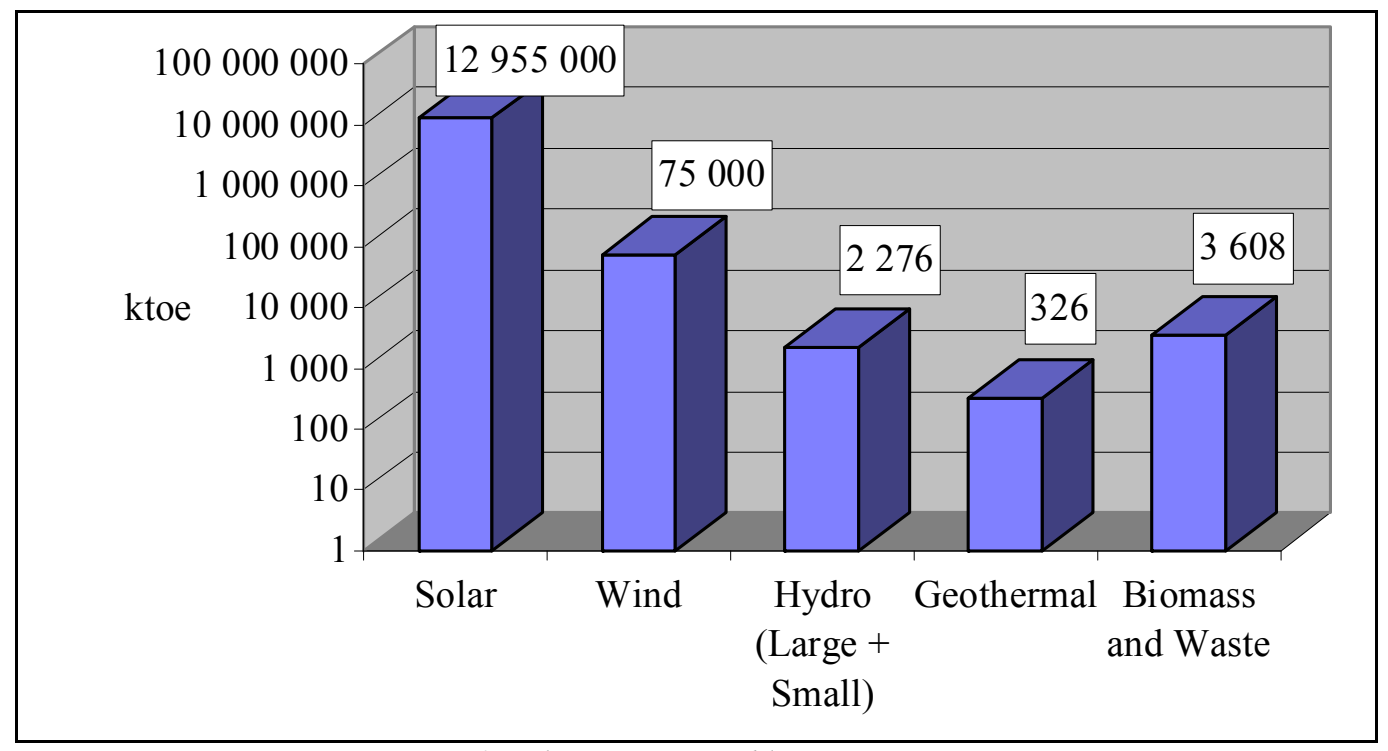

Figure 4. Bulgarian Renewable Energy Resource 


\section{RENEWABLE ENERGY TECHNOLOGIES - PRESENT STATUS AND INSTALLED CAPACITY}

The renewable energy technologies are at different stages of development. Geothermal and solar energy have been widely studied and utilised whereas wind power has virtually no installed capacity at all except for water pumping. Small hydro installations have been installed over many years but the overall capacity is still quite low (Table 1). Biomass has an enormous installed capacity in the domestic, agricultural and industrial sectors but reliable data on the precise amount is very difficult to find. This section considers in brief the present status of renewable energy technologies and their installed capacities.

\section{Solar}

Solar thermal water heating. There are 50000 $\mathrm{m}^{2}$ plane collectors installed largely in hotels for catering and some process heating such as bottle washing. The breakdown of the installed capacity by regions is shown in Table 5.

Table 5. Installed Capacity of Solar Water Heating and Biomass Boilers

\begin{tabular}{|l|c|c|}
\hline Region & $\begin{array}{c}\text { Installed Solar } \\
\text { Water Heating } \\
\text { Capacity, } \\
\mathrm{m}^{2} \text { of Panel Area }\end{array}$ & $\begin{array}{c}\text { Installed Bio- } \\
\text { mass Boiler } \\
\text { Capacity, } \\
\text { MW }\end{array}$ \\
\hline Bourgas & 17100 & 1.0 \\
\hline Haskovo & 6300 & - \\
\hline Lovech & 1450 & 1.4 \\
\hline Montana & 950 & 2.5 \\
\hline Plovdiv & 6300 & 6.2 \\
\hline Rousse & 950 & - \\
\hline Sofia City & 2200 & 3.85 \\
\hline Sofia Region & 6800 & 30.0 \\
\hline Varna & 4725 & - \\
\hline Total & 46775 & 44.95 \\
\hline
\end{tabular}

Passive solar design. There is only one example of a passive solar house. From monitoring of this house for a one month period it was found that the passive solar contribution was $30 \%$ of the load. There is clearly a good potential for passive solar heating given the good solar resource and the large heating demand.

Solar photovoltaics (PV). The Solar Energy Laboratory of the Bulgarian Academy of Sciences has designed their own PV cells and produced a small quantity of PV modules for testing and demonstration only. Two $1.5 \mathrm{kWp}$ each PV grid connected systems have been installed in Bulgaria in the framework of INCO-COPERNICUS Programme of the European Commission [4].

Wind

There are one or two examples of small wind generators in Bulgaria but there is a little general experience. A $5 \mathrm{~kW}$ imported from Russia generator is installed at the hotel at the Black Sea.

Several companies produce wind pumps for agricultural pumping with $3 \div 4$ metres water depth.

\section{Small Hydro}

Hydro generation represents a modest, but important $6.9 \%$ share in Bulgarian energy needs (World Bank 1993). The present installed capacity is $2000 \mathrm{MW}$, of which $25 \mathrm{MW}$ is small hydro. The average annual energy generated for the period from 1979 to 1993 was $2734 \mathrm{MWh}$, with an average plant factor (for both small and large hydro) of $16.1 \%$, and a load factor of $37 \%$ for small hydro. The present installed capacity for small hydro by region is shown in Table 1.

Majority of small hydro in Bulgaria is grid connected, and this will continue to be the predominant use. Given the extent of the grid, there is a little demand for stand-alone small hydro, but there are encouraging signs that private enterprise is showing interest in the potential small hydro market.

Geothermal

Geothermal energy has been utilised in Bulgaria for heating purposes in addition to its balneological uses for thousands of years [5]. Modern installations for space heating in buildings and greenhouses date back from nearly one hundred years ago. Considerable technological work was carried out during the 1970s and 1980s. This effectively stopped during the late 1980s with the political and economic changes that swept Bulgaria. The best figures on installed capacity are presented in Table 2 and illustrated in Figure 5.

\section{Biomass and Waste}

Assessing installed biomass capacity in the market sectors has proved to be very difficult. The biomass user survey has produced some very revealing statistics about the amount of wood fuel being 
used in Bulgaria. Household wood consumption is high. It is $5 \mathrm{~m}^{3}$ per household per annum on the average. Over $4,7.10^{6} \mathrm{~m}^{3}$ of wood $\left(2.10^{6}\right.$ tonnes) per annum are being used for household energy purposes in rural areas. An estimate for the commercial and industrial sectors is shown in Table 5.
For biomass to play a more significant role in the Bulgarian fuel economy consumers, would have to be familiarised with the new equipment and techniques for biomass fuel utilisation.

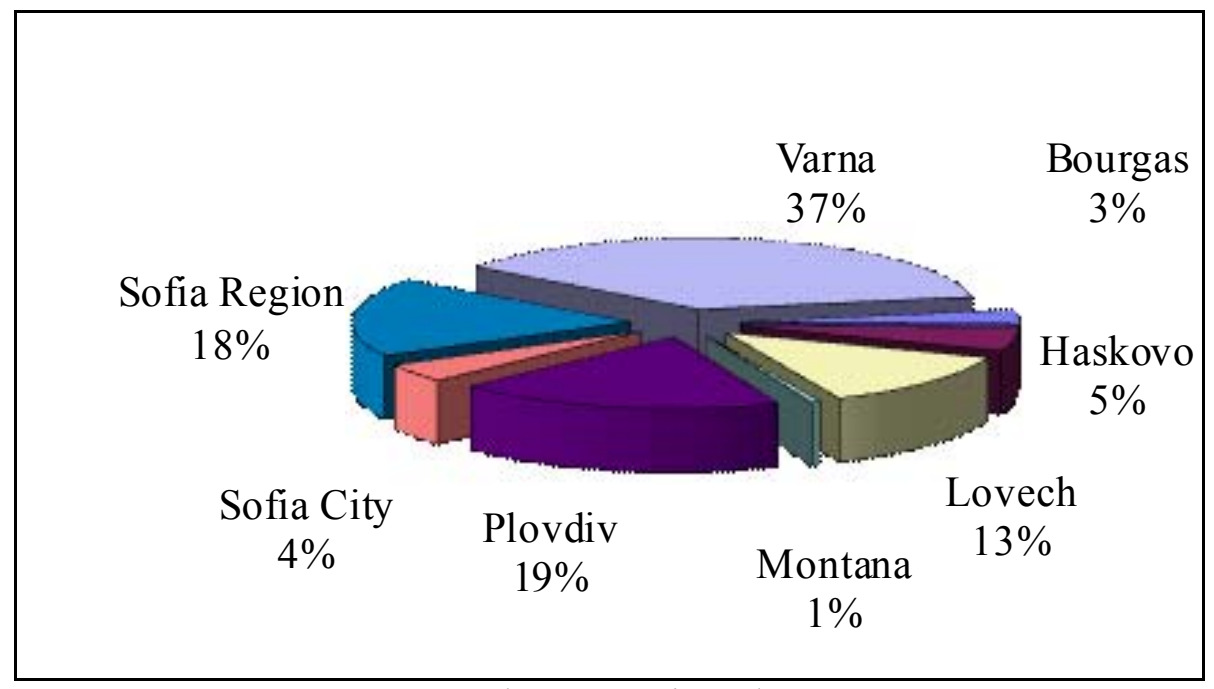

Figure 5. Bulgarian Geothermal Capacity

\section{CONCLUSIONS}

The carried out research shows that Bulgarian rich renewable energy resource base can be tapped extensively and sustainably.

Bulgaria has numerous opportunities to develop its renewable energy source base. Its people have a high level of technical educational skills. Bulgaria has the infrastructure to support the development and exploitation of renewable energy to a much greater extent than many countries in Europe. It has a long history of renewable energy utilisation. The general population has a great interest in further development of renewable energy.

On the other hand, there are some constrains for development of renewables. Both the general public and senior government officials do not know much about renewable energy, or its potential to contribute towards Bulgaria's development. They have insufficient understanding of the ability of renewables to improve the environment, to stimulate industrial development, to generate jobs, to reduce the country dependency on imports or to generate government revenues. Moreover, prices of energy have put renewables at a disadvantage for many years. There are almost no government initiatives or incentives to encourage the development and use of renewable energy. There is a lack of financial support for renewable energy projects.

\section{REFERENCES}

[1] M. Bess, Evaluation of Renewable Energy Resources in Bulgaria. In Proceedings of Bulgarian National Energy Forum '97, Droujba, Varna, Bulgaria, 1997, 124-131.

[2] S. Shtrakov et al., Current Situation and Prospects of Renewable Energy Sources in Bulgaria. In Proceedings of EMF ' 97 Conference, Sozopol, Bulgaria, 1997, 138-141.

[3] Climatic of Bulgaria handbook, Volume 1, Science and Art Publishing House, Sofia, 1981.

[4] N. Tutundjiev, P. Vitanov, Stand-Alone PV Pumping System. In Proceedings of Bulgarian National Energy Forum '97, Droujba, Varna, Bulgaria, 1997, 138-141.

[5] Proceedings of Third National Conference Renewable Energy Sources, Bulgarian Academy of Sciences, Sofia 2003. 


\section{$\operatorname{son} 2$}

\section{МОГУЋНОСТИ КОРИШЋЕЊА ОБНОВЉИВИХ ИЗВОРА ЕНЕРГИЈЕ У БУГАРСКОЈ}

Сажетак: Бугарска има једну од најјачих база обновљивих извора енергије у Европи. У овом раду представљена је процјена бугарских обновљивих извора енергије као једна од фаза у повећању удјела који ови извори имају у укупном енергетском билансу земље, у побољшању еколошких услова, стимулисању индустријског развоја и отварању нових радних мјеста. Разматра се теоријски (укупни) енергетски потенцијал сунца, вјетра, хидропотенцијал, велики и мали, геотермални, потенцијал биомасе и отпада. У раду је приказан статус технологија за обновљиве изворе и њихових инсталираних капацитета. Разматрају се шансе и ограничења за развој и коришћење обновљиве енергије.

Кључне ријечи: теоријски енергетски потенцијал, соларни, ресурс вјетра, хидро, геотермални и потенцијал биомасе. 